\title{
HEMATOLOGICAL STUDY IN THREE LINES OF QUAIL AND THEIR CROSSES
}

\author{
Ronak A. Meshabaz ${ }^{* a}$, Kurdman M. Sulaiman ${ }^{\text {b }}$, Shekhmous H. Hussen ${ }^{\text {b }}$, Mwafaq S. Berwary ${ }^{\text {b Jamila H. Saleh }}{ }^{\text {b }}$, Saif A. Ahmed ${ }^{\text {b }}$ and Najat J. \\ Mohammed ${ }^{\mathrm{b}}$.
}

Dept. of environmental science, faculty of science, University of Zakho, Kurdistan Region, Iraq. (ronak.abdelaziz@uod.edu.krd) Dept. of Animal Production, College of Agriculture, University of Duhok, Kurdistan Region, Iraq

\begin{abstract}
:
The present study was conducted at poultry laboratories, department of animal production, Agriculture College, Duhok University, Kurdistan region, Iraq, (2016). Three lines of quail (White, light brown and dark brown) and their crosses that resulted from diallel cross design; aged 8 weeks old were used. A total of 54 blood samples by about $5 \mathrm{ml}$, from both sexes within each genotype aged 8 weeks old, were collected directly after slaughtering and bleeding for 3 second. PVC \%, hemoglobin (Hb), Hetrophyl (H), Lymphocyte (L), H/L ratio, total protein, globulin, albumen and cholesterol were studied. The results showed insignificant differences among genotypes and between sexes for both $\mathrm{PVC}$ and $\mathrm{Hb}$, while $\mathrm{H}, \mathrm{L}, \mathrm{H} / \mathrm{L}$, total protein, globulin, albumen and cholesterol appeared high significant $(\mathrm{p}<0.01)$ differences among the nine studied genotypes. The effect of sex was significant $(\mathrm{p}<0.05)$ for $\mathrm{H}, \mathrm{L}$ and cholesterol. Interaction between genotype and sex was just significant for albumen. There was a significant negative correlation between $\mathrm{H} / \mathrm{L}$ ratio and globulin (-0.39). Dependence of $\mathrm{H} / \mathrm{L}$ ratio on globulin, resulted in derives a prediction equation.
\end{abstract}

Keywords: Quail, Hematological parameters, Genotypes, Crosses.

\section{INTRODUCTION}

Crossing in poultry plays an important role in changing the values of some blood parameters; On the other hand, the blood parameters affected by different factors such as genotype, sex, physiological conditions and laying period (Suchy et al. 2000; Gyenis et al. 2006; Pavlik et al. 2009). Poultry genotypes resulted from crossing need to be tested physiologically through blood samples, in older to know how the hematological parameters may change by crossing.

Dowidar et al. (1999) reported significant differences in total protein and cholesterol of chicken's blood samples. Hematological studies on some poultry species exposed to cross breeding were investigated by several studies (Elnaggar et al. 2001; El-Kaiaty \&Hassan, 2004; El-Tahawy, 2005 and Abd El-Aziz, 2006). A study on J. quail conducted by Farahat et al. (2010), showed that all studied hematological parameters (Ht \%, Hb, RBC, WBC, Hetrophyl and Lymphocytes) were not statistically significant between both sexes, they added that all these parameters correlated significantly to each other, and they concluded that blood parameters in J. quail may use as selection criteria for genetic improvement in the future. However, several research workers indicated changing in some blood biochemical parameters in chicken's breeds and their cross, such as Hetrophyl to Lymphocytes ratio (H/L ratio) (Fathi et al., 2005) total protein, albumen and globulin (Mahrous et al., 2008); total cholesterol (Mahrous and El- Dlebshany, 2011). Moreover, (Peters et al. 2011) reported significant $(p<0.05)$ difference between pure breeds and their crosses in respect to PCV, serum glucose, cholesterol and globulin in Nigerian native fowl. Aly et al. (2006), mentioned significant differences among all studied genotypes (pure strains and their crosses) of Egyptian local strain of chickens concerning all studied blood hematology parameters, they added that to concerning blood biochemical parameters, the pure strains had nearly significantly similar averages of serum protein, while one strain had the highest serum albumin average and the other strain had the highest cholesterol content, which mean that the hematological and biochemical parameters may differed from strain to another. So, the present investigation aimed to study some hematological and biochemical parameters in blood samples of three quail lines and their crosses.

\section{MATERIAL AND METHODS}

The present study was conducted at poultry laboratories, department of animal production, Agriculture College, Duhok University, Kurdistan region, Iraq in 2016. Three lines of quail (White, light brown and dark brown) were reared and crossed using full diallel cross design; nine genotypes were obtained as progeny (three genotypes from each of pure breeds, crosses and their reciprocal crosses). The experiment was done on the progeny. Management and rearing conditions were same as possible throughout the whole trial periods, where the light was provided as $15 \mathrm{~h} / \mathrm{d}$. The amount of energy and protein in the ration submitted to the layer show in table (1).

Table 1. Amount of energy and protein of the Layer ration which submitted to the birds during the trial period

\begin{tabular}{|l|l|}
\hline Calculated Chemical composition \\
\hline ME (Kcal/kg) & 2838.4 \\
\hline Crude protein (\%) & 17.83 \\
\hline
\end{tabular}

\subsection{Blood sample collection and analysis}

A total of 54 blood samples by about $5 \mathrm{ml}$, from both sexes within each genotype of quail birds aged 8 weeks old, were collected directly after slaughtering and bleeding for 3 second. $2 \mathrm{ml}$ of the blood was dropped into the test tube containing ethylene diamine tetra-acetic acid (EDTA) for hematological parameters; packed cell volume (PCV) or hematocrit,

\footnotetext{
* Corresponding author

This is an open access under a CC BY-NC-SA 4.0 license (https://creativecommons.org/licenses/by-nc-sa/4.0/)
} 
hemoglobin concentration $(\mathrm{Hb})$, Heterophil $(\mathrm{H}) /$ lymphocyte (L) ratio (H/L ratio) analysis. The other $3 \mathrm{ml}$ was placed in sterilized glass test tubes without anticoagulant and left at room temperature for two hours, then centrifuged (3000 RPM) for 15 min and the serum was discrete by micropipette and put into tubes. After that it stored at $-20{ }^{\circ} \mathrm{C}$ until the analysis for biochemical parameters; total protein (TP), albumin (A), globulin $(\mathrm{G})$ and cholesterol $(\mathrm{Ch})$.

The (PCV) was determined by the micro hematocrit method (Archer, 1965). The capillary tube was filled with blood then closed with rubber mud immediately, after that put in the micro-hematocrit centrifuge for 15 minutes, then calculate the percentage of the size of blood cells by using a special ruler. The hemoglobin concentration estimated by using Drabkin's reagent which converts hemoglobin to a Cyanomethemoglobin, $20 \mu \mathrm{l}$ of blood was mixed with $5 \mathrm{ml}$ of reagent then placed in the centrifuge speed $(5000 \mathrm{r} / \mathrm{min}$ ) for 15 minutes to get rid of nuclei and membrane of red blood cells, then redd by spectrophotometer according to Varley et al, (1980).

Granular (heterophils) and non-granular (lymphocyte) ratio was calculated by using a drop of blood on the slide and distributed by another slide at an angle of 45 without the pressure, then pigmented with Gimsa stain for 15 mints and washed with distell water after the smear was drying and the numbers were read Heterophil and lymphocyte under microscope on the strength enlarges $\times 100$ (put a drop of oil on the slide).

Serum cholesterol concentration, total protein and albumin were determined by using analyzing material (kit) produced by BIOLAB SA, France by using spectrophotometers. Globulin was calculated as the difference between total protein and albumin.

\subsection{Statistical analysis}

The collected data were analyzed statistically by SAS software (SAS, Institute, 2010) using GLM procedure and according to the following models:

$$
Y_{i j k}=\mu+G_{i}+S_{j}+\left(G^{*} S\right)_{i j}+e_{i j k}
$$

Where: $\boldsymbol{Y}_{i j k}=$ the studied parameters in $k$ bird of $j$ sex and $i$ genotype; $\boldsymbol{\mu}=$ the overall mean; $\boldsymbol{G}_{i}=$ the effect of genotype; $S_{j}$ $=$ the effect of sex; $\left(G^{*} S\right)_{i j}=$ the interaction between the genotype and sex and $\boldsymbol{e}_{i j k}=$ the experimental error.

The correlation coefficients between studied parameters and the dependence of $\mathrm{H} / \mathrm{L}$ ratio on globulin parameter were analyzed within the same software. The differences between sexes mean and among genotypes means were tested by Duncan multiple ranges test (Duncan, 1955).

\section{RESULTS AND DISCUSSION}

\subsection{Hematological parameters:}

\subsubsection{PCV \% and Hemoglobin:}

The results of both Hematocrit (PCV \%) and Hemoglobin $(\mathrm{g} / \mathrm{dl})$ as affected by the studied genotypes are represented in Table (2). There are insignificant differences among all genotypes for both studied parameters $(P>0.05)$, but it could be noticed that LD cross genotype recorded the highest PCV $(44.25 \%)$ with the lowest CV $(8.7 \%)$, while the lowest percentage of PCV was recorded by WD cross genotype (34.3 $\%)$ with intermediate CV $(11.8 \%)$. Also, the other genotypes were resulted in relatively medium to high $\mathrm{CV} \%$ for the PCV $\%$, which reflect the presence of some extreme values that showed insignificant differences among the genotypes. The same trend was found for Hemoglobin values, because the latter one derived from the former. The present results are in agreement with the findings of Dief et al. (2007) who reported insignificant differences in Hematocrit \% between two broiler strains. On the other hand, the present results are disagreement with the findings that reported by Galal et al. (2008) on laying hens.

Table 2. Effect of genotype on both hematocrit and hemoglobin

\begin{tabular}{|c|c|c|c|c|c|}
\hline \multicolumn{2}{|c|}{ Genotype } & \multicolumn{2}{|c|}{ Hematocrit (PCV \% ) } & \multicolumn{2}{c|}{ Hemoglobin (g/dl) } \\
\cline { 3 - 6 } \multicolumn{2}{|c|}{} & Mean \pm SE & CV\% & Mean \pm SE & CV\% \\
\hline \multirow{3}{*}{ Purebred } & WW & $33.5 \pm 2.3$ & 13.4 & $11.15 \pm 0.74$ & 13.5 \\
\cline { 2 - 6 } & LL & $33.75 \pm 1.5$ & 8.8 & $11.2 \pm 0.5$ & 8.7 \\
\cline { 2 - 6 } & DD & $37.75 \pm 3.1$ & 16.4 & $12.58 \pm 1.0$ & 16.4 \\
\hline \multirow{3}{*}{ Crosses } & WL & $37.33 \pm 5.0$ & 23.4 & $12.4 \pm 1.7$ & 23.3 \\
\cline { 2 - 6 } & WD & $34.3 \pm 2.3$ & 11.8 & $11.4 \pm 0.75$ & 11.5 \\
\cline { 2 - 6 } & LD & $44.25 \pm 1.9$ & 8.7 & $14.7 \pm 0.6$ & 8.7 \\
\hline Reciprocal crosses & LW & $33.5 \pm 4.3$ & 25.8 & $11.12 \pm 1.4$ & 25.8 \\
\cline { 2 - 6 } & DW & $37 \pm 3.4$ & 18.3 & $12.27 \pm 1.1$ & 18.4 \\
\cline { 2 - 6 } & DL & $40.5 \pm 2.3$ & 11.5 & $13.48 \pm 0.8$ & 11.3 \\
\hline & Sig. & ns & & $\mathrm{ns}$ & \\
\hline
\end{tabular}

The means with different letters differ significantly.

Regarding to the effect of sex on both PCV \% and Hemoglobin, the results showed insignificant effect $(P>0.05)$ as illustrated in Fig. 1. However, the interaction between genotype and sex was insignificant. On the contrary of the, Kosshak et al. (2014) who found that females of quail had higher values of hemoglobin than males, and they attributed their result to the fact that before sexual maturity age, the physiological parameters changes in metabolism of female of J. quail, while PCV \% had no significant differences between both sexes.

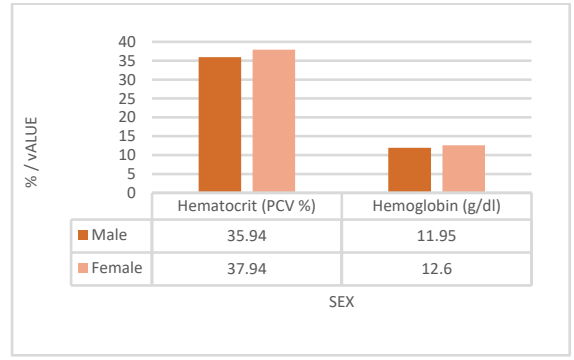

Figure 1. Effect of sex on both PCV and hemoglobin in genotypes quail.

3.1.2 Heterophil and Lymphocyte

The results of heterophil, lymphocyte and their ratio as affected by studied genotypes are representing in table (3). As it is shown, there are a significant $(P<0.01)$ differences among the studied genotypes for $\mathrm{H}, \mathrm{L}$ and $\mathrm{H} / \mathrm{L}$. Regarding to $\mathrm{H}$, the results 
showed that the pure line $\mathrm{W}$ had the highest value (59.25) with the lowest CV \%, while the LL and LD crosses had the lowest $\mathrm{H}$ value with (25 and 29.5 , respectively) with relatively high $\mathrm{CV} \%$. The all other genotypes had intermediate values. This result indicates that $\mathrm{W}$ line may have a high immunity response to bacterial infections, while L line and LD crosses have the lowest response. In respect to lymphocyte, the opposite results were found, where the pure line L line and the cross LD have the highest values ( 75 and 70.5 , respectively), while the lowest value was recorded for the pure line W (40.8), and the other genotypes were recorded intermediate values. This finding may illustrate the possible high response of both $\mathrm{L}$ and LD genotypes to viruses, while the opposite is right for $\mathrm{W}$ pure line, which was affective against bacteria. In regard to $\mathrm{H} / \mathrm{L}$ ratio, the results showed that the highest ratio was recorded for the $\mathrm{W}$ pure line (1.48) and the lowest one was recorded for the $\mathrm{L}$ pure line (0.33), this insure the possibility of $\mathrm{W}$ pure line to response more to bacteria than all the other genotypes, while the $\mathrm{L}$ pure line more response to viruses. The remaining crosses (including LD cross) and reciprocal crosses had intermediate response to both bacteria and viruses, because $\mathrm{H} / \mathrm{L}$ ratio is determining the immunity response not $\mathrm{H}$ or $\mathrm{L}$ alone. Makram et al. (2014) reported significant differences between duck strains for $\mathrm{H}$ and L.

Table 3. Effect of genotype on hetrophil, lymphocyte and hetophil/lymphocyte ratio

\begin{tabular}{|c|c|c|c|c|c|c|c|}
\hline \multirow{2}{*}{\multicolumn{2}{|c|}{ Genotype }} & \multicolumn{2}{|l|}{ Hetrophile } & \multicolumn{2}{|l|}{ Lymphocyte } & \multicolumn{2}{|c|}{ Hetrophil / lymphocyte } \\
\hline & & Mean \pm SE & CV\% & Mean \pm SE & CV\% & Mean \pm SE & $\mathrm{CV} \%$ \\
\hline \multirow{3}{*}{$\begin{array}{l}\vec{\Xi} \\
\stackrel{0}{0} \\
0 \\
0 \\
0\end{array}$} & WW & $59.25 \pm 2.8^{\text {a }}$ & 9.6 & $40.8 \pm 2.8^{\mathrm{e}}$ & 13.9 & $1.48 \pm 0.2^{\mathrm{a}}$ & 26.4 \\
\hline & LL & $25 \pm 1.8^{\mathrm{e}}$ & 14.2 & $75 \pm 1.8$ & 4.7 & $0.33 \pm 0.03^{\mathrm{e}}$ & 20.6 \\
\hline & DD & $30.75 \pm 3.9^{\mathrm{de}}$ & 25.6 & $69.25 \pm 3.9^{\mathrm{ab}}$ & 11.4 & $0.46 \pm 0.07^{\mathrm{de}}$ & 34.3 \\
\hline \multirow{3}{*}{$\begin{array}{l}0 \\
0 \\
0 \\
0 \\
0\end{array}$} & WL & $33.75 \pm 2.4^{\text {cde }}$ & 14.2 & $66.25 \pm 2.4^{\mathrm{abc}}$ & 7.2 & $0.52 \pm 0.05^{\text {cde }}$ & 22.1 \\
\hline & WD & $38.75 \pm 4.3^{\mathrm{bcd}}$ & 22.0 & $61.25 \pm 4.3^{\mathrm{bcd}}$ & 13.9 & $0.66 \pm 0.1 \quad$ bcd & 37.4 \\
\hline & LD & $29.5 \pm 3.8^{\mathrm{e}}$ & 25.7 & $70.5 \pm 3.8^{\mathrm{a}}$ & 10.8 & $0.43 \pm 0.1$ de & 39.6 \\
\hline \multirow{3}{*}{ 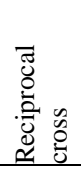 } & LW & $44.25 \pm 2.2^{b}$ & 9.8 & $55.75 \pm 2.2^{\mathrm{d}}$ & 7.8 & $0.80 \pm 0.1^{\mathrm{b}}$ & 18.1 \\
\hline & DW & $40.25 \pm 2.3^{\mathrm{bc}}$ & 11.2 & $59.75 \pm 2.3^{\mathrm{cd}}$ & 7.5 & $0.68 \pm 0.1$ bcd & 18.6 \\
\hline & DL & $42 \pm 3.6^{\mathrm{bc}}$ & 17.3 & $58 \pm 3.6^{\text {cd }}$ & 12.5 & $0.75 \pm 0.1 \mathrm{bc}$ & 29.1 \\
\hline \multicolumn{2}{|c|}{ Sig. $(p)$} & \multicolumn{2}{|l|}{0.0001} & \multicolumn{2}{|l|}{0.0001} & \multicolumn{2}{|l|}{0.0001} \\
\hline
\end{tabular}

Regarding to the effect of sex on $\mathrm{H}, \mathrm{L}$ and $\mathrm{H} / \mathrm{L}$ ratio, the Fig. (2). It was illustrated that males were significantly $(P<0.05)$ surpassed females for $\mathrm{H}$, while the opposite was true for $\mathrm{L}$, where females were significantly $(P<0.05)$ surpassed males. This may mean that the quail male response to bacteria more than female, while the latter is more response to viruses) Uduak et al. 2015). The present results are disagreement with that found by Farahat et al. (2010) who reported insignificant differences between both sexes for $\mathrm{H}$ and $\mathrm{L}$. However, Muhammad (2013) illustrated that $\mathrm{H} / \mathrm{L}$ ratio of adult females of golden feathers quail was higher than those of males. The interaction between genotype and sex was insignificant.

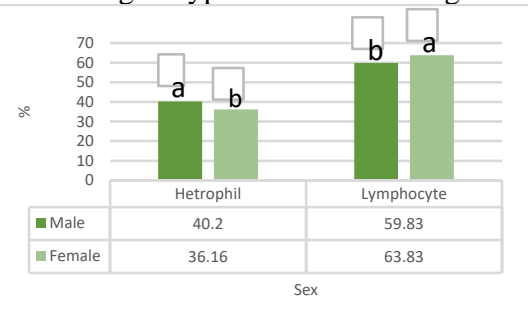

Figure 1. Effect of sex on both Hetrophil and Lymphocyte

\subsection{Biochemical parameters:}

The results of biochemical parameters are represented in Table (4). It could be noticed that all studied parameters were different significantly $(p<0.01)$ among the studied genotypes. Total protein parameter in the cross LD and both reciprocal crosses LD \& DW had the highest values (46.25-47.25 g/l) with small CV \% compared to the other genotypes. However, the lowest value was recorded to $\mathrm{W}$ line $(30.25 \mathrm{~g} / \mathrm{l})$. Regarding to Albumen, the same trend of total protein for the highest values was found, but the lowest values were recorded for D line and WL cross. In respect to globulin, it could be noticed that the reciprocal cross LW had the highest value (34.02 g/l), while the lowest ones was recorded by W line and cross WL (15.8- 18.9 $\mathrm{g} / \mathrm{l})$. This finding may illustrate that when L line used as a sire and $\mathrm{W}$ line used as a dam, resulted in the best immunity response, and the opposite is true when the former used as a dam and the later used as a sire. The result of cholesterol in the previous table (4), showed the superiority of the cross WD $(103.8 \mathrm{mg} / \mathrm{dl})$ on the remaining genotypes, while the lowest one was recorded for the $\mathrm{L}$ line $(71.75 \mathrm{mg} / \mathrm{dl})$, this result may reflect the interaction between both purposes of production in respect to raising cholesterol, because both meat and egg yield are sharing to elevate the triglycerides contents, while the other genotypes may include L line (which considered as dual purpose line) as a sire or as a dam. The present results are in agreement with Aly et al. (2006) findings on chickens and Uduak et al. (2013) findings on Turkey for the most biochemical studied parameters. 
Table 4. effect of genotypes on biochemical parameters

\begin{tabular}{|c|c|c|c|c|c|c|c|c|c|}
\hline \multirow{2}{*}{\multicolumn{2}{|c|}{ Genotype }} & \multicolumn{2}{|c|}{ Total protein $(\mathrm{g} / \mathrm{l})$} & \multicolumn{2}{|c|}{$\operatorname{Albumin}(\mathrm{g} / \mathrm{l})$} & \multicolumn{2}{|c|}{ Globulin (g/l) } & \multicolumn{2}{|c|}{ Cholesterol(mg/dl) } \\
\hline & & Mean \pm SE & $\mathrm{CV} \%$ & Mean \pm SE & $\mathrm{CV} \%$ & Mean \pm SE & $\mathrm{CV} \%$ & Mean \pm SE & $\mathrm{CV} \%$ \\
\hline \multirow{3}{*}{ 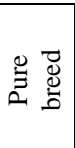 } & WW & $30.25 \pm 1.4^{\mathrm{c}}$ & 9.5 & $14.5 \pm 1.3^{\mathrm{ab}}$ & 18.2 & $15.8 \pm 2.6^{\mathrm{d}}$ & 32.5 & $88 \pm 3.02^{b c}$ & 6.9 \\
\hline & LL & $37 \pm 2.1^{\mathrm{bc}}$ & 9.7 & $14.4 \pm 0.3^{\mathrm{ab}}$ & 3.8 & $22.56 \pm 2.4^{\mathrm{cd}}$ & 18.4 & $71.75 \pm 4.2^{\mathrm{d}}$ & 11.7 \\
\hline & DD & $43.5 \pm 5.5^{\mathrm{ab}}$ & 25.3 & $12.5 \pm 0.2^{\mathrm{c}}$ & 3.4 & $31 \pm 5.4^{\mathrm{abc}}$ & 34.7 & $87.5 \pm 1.8^{\mathrm{bc}}$ & 4.2 \\
\hline \multirow{3}{*}{ 幽 } & WL & $31.75 \pm 1.4^{\mathrm{c}}$ & 8.6 & $12.8 \pm 0.1^{\mathrm{c}}$ & 1.7 & $18.9 \pm 1.3^{\mathrm{d}}$ & 13.5 & $97 \pm 0.7^{\mathrm{ab}}$ & 1.4 \\
\hline & WD & $37.5 \pm 3.4^{\mathrm{bc}}$ & 18.2 & $13.5 \pm 0.33^{\mathrm{bc}}$ & 4.5 & $24 \pm 3.6^{\text {bcd }}$ & 30.2 & $103.8 \pm 5.5^{\mathrm{a}}$ & 10.6 \\
\hline & LD & $46.25 \pm 0.8^{a}$ & 3.4 & $15.15 \pm 0.2^{\mathrm{a}}$ & 3.2 & $31.1 \pm 1.1^{\mathrm{abc}}$ & 6.9 & $78.75 \pm 1.5^{\mathrm{cd}}$ & 3.8 \\
\hline \multirow{3}{*}{$\underset{\mathscr{D}}{\stackrel{0}{0}}$} & LW & $49.25 \pm 1.4^{\mathrm{a}}$ & 5.6 & $15.22 \pm 0.3^{\mathrm{a}}$ & 3.5 & $34.02 \pm 1.5^{\mathrm{a}}$ & 8.8 & $80 \pm 3.5^{\mathrm{cd}}$ & 8.8 \\
\hline & DW & $47.25 \pm 0.9^{\mathrm{a}}$ & 3.6 & $15.05 \pm 0.3^{\mathrm{a}}$ & 3.3 & $32.2 \pm 1.1^{\mathrm{ab}}$ & 6.6 & $74 \pm 5.1^{\mathrm{d}}$ & 13.8 \\
\hline & $\mathrm{DL}$ & $36.25 \pm 1.4^{\mathrm{bc}}$ & 7.6 & $14.1 \pm 0.3^{\mathrm{ab}}$ & 4.2 & $22.15 \pm 1.5^{\mathrm{cd}}$ & 13.6 & $82.25 \pm 4.0^{\mathrm{cd}}$ & 9.8 \\
\hline \multicolumn{2}{|c|}{ Sig. $(p)$} & \multicolumn{2}{|c|}{0.0005} & \multicolumn{2}{|c|}{0.0001} & \multicolumn{2}{|l|}{0.001} & \multicolumn{2}{|c|}{0.0001} \\
\hline
\end{tabular}

The means with different letters differ significantly.

Effect of sex on the studied biochemical parameters was significant $(p<0.05)$ only for cholesterol, where males had higher cholesterol level than females, the other parameters were not significantl $(p>0.05)$. The present results are in agreement with the findings of Uduak et. al. (2013) in respect to all biochemical parameters except cholesterol level which was insignificant.

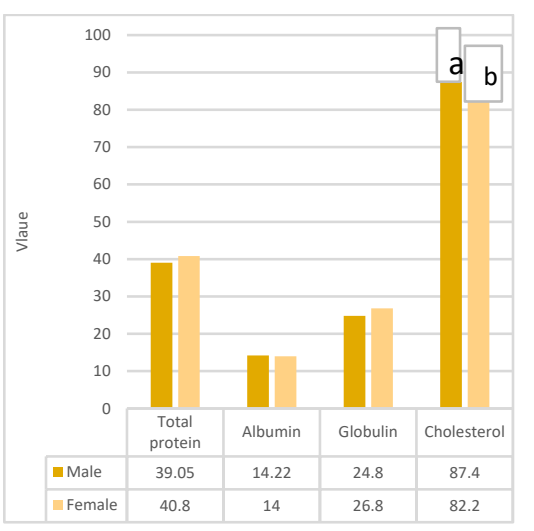

Figure 2. Effect of sex on biochemical parameters

However, the interaction between genotype and sex was insignificant for all biochemical parameters except albumen (Fig. 3), where the male of $\mathrm{W}$ line resulted in the highest value $(16.5 \mathrm{~g} / \mathrm{l})$.

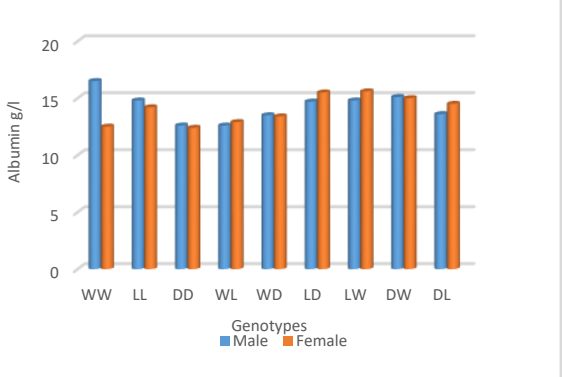

Figure 3. The interaction between genotype and sex on quail's albumin.

\subsection{The relationship between hematological and biochemical parameters}

The correlation coefficients between the studied hematological and biochemical parameters are shown in Table (5). It could be seen that most correlation coefficients are significant, and the highest positive significant $(p<0.01)$ coefficient was recorded between total protein and globulin (0.98), this result is logical because the later derived from the former, while the highest negative significant $(p<0.05)$ correlation coefficient was recorded between total protein and cholesterol $(-0.41)$, this result insure that protein play a reverse role to cholesterol (because cholesterol represent one of the most important compound of fat in the body). Also, it could be noticed that $\mathrm{H} / \mathrm{L}$ ratio is correlated negatively and significantly $(p<0.05)$ to globulin (-0.39), which mean that globulin value increase as $\mathrm{H} / \mathrm{L}$ ratio decrease, this result indicate that globulin may work more as immunity defense system in case of virus attack more than the bacteria attack in the quail body. As it noticed from the Table (5) also, that $\mathrm{H} / \mathrm{L}$ ratio correlated negatively and significantly $(p<0.05)$ to total protein $(-0.35)$, this result reflects the importance of protein in immunity response especially in case of virus attack. On the contrary, the correlation coefficient between $\mathrm{H} / \mathrm{L}$ ratio and albumen is positive and significant $(0.33)$, because albumen is the second component of total protein beside the globulin which was negative. Contrary to the relationship between $\mathrm{H} / \mathrm{L}$ ratio and protein components, cholesterol seem to be play a reverse role with $\mathrm{H} / \mathrm{L}$ ratio, where the correlation coefficient was negative and significant $(p<0.05)$ between cholesterol and albumen (0.36 ), while the correlation coefficient between cholesterol and globulin was positive and significant $(p<0.05)$ and estimated as (0.34). This result is logical because of negative significant correlation between both total protein and cholesterol. Unfortunately, and according to global research, there were no references about the relationship between hematological and biochemical parameters in blood of quail resulted from diallel cross.

Table 5. Correlation coefficients between different blood parameters

\begin{tabular}{|l|r|r|r|r|r|}
\hline & $P C V$ & $\begin{array}{c}\text { HL } \\
\text { ratio }\end{array}$ & $\begin{array}{c}\text { total } \\
\text { protein }\end{array}$ & albumin & globulin \\
\hline HL ratio & -0.21 & 1 & & & \\
\hline $\begin{array}{l}\text { total } \\
\text { protein }\end{array}$ & $0.29 *$ & $-0.35 *$ & 1 & & \\
\hline Albumin & $0.05 *$ & $0.33 *$ & 0.21 & 1 & \\
\hline Globulin & 0.28 & $-0.39 *$ & $0.98 * *$ & 0.05 & 1 \\
\hline cholesterol & -0.11 & 0.18 & $-0.41 *$ & $-0.36^{*}$ & $0.34^{*}$ \\
\hline
\end{tabular}

However, the linear regression analysis (Table 6) shows the dependence of $\mathrm{H} / \mathrm{L}$ ratio on the globulin $(\mathrm{g} / \mathrm{l})$, in another word, it could be predicted with $\mathrm{H} / \mathrm{L}$ ratio (as indicator to the hematological immunity response) from the globulin parameter value (biochemical immunity indicator). But unfortunately, the coefficient of determination (R2) value for the prediction equation is limited (0.15), which prevent the present research to suggest this result as single indicator of immunity in the quail. The final prediction equation will be as following:

$\mathrm{H} / \mathrm{L}$ ratio $=\mathbf{- 0 . 0 2} *($ Globulin value $)+\mathbf{1 . 1 7}$ 
If the final resulted value is higher than 1 , then the immunity of the quail is responding to the bacteria more than viruses, but in the opposite case the response will be more active against viruses. This way will help to predict the immunity response without measuring both $\mathrm{H}$ and $\mathrm{L}$, in addition to eliminate the calculation of $\mathrm{H} / \mathrm{L}$ ratio. Unfortunately, and despite to a wide survey there was no similar research which deal the same problem concerning with the prediction of $\mathrm{H} / \mathrm{L}$ ratio from globulin in quail.

Table 6. Regression analysis for the dependence of $\mathrm{H} / \mathrm{L}$ ratio on

\begin{tabular}{|l|r|r|r|r|}
\hline Multiple R & 0.392645 & & & \\
\hline R Square & $\mathbf{0 . 1 5 4 1 7}$ & & & \\
\hline & Coefficients & $\begin{array}{c}\text { Standard } \\
\text { Error }\end{array}$ & t Stat & P-value \\
\hline Intercept & $\mathbf{1 . 1 6 4 5 4 2}$ & 0.205511 & 5.666575 & $2.34 \mathrm{E}-06$ \\
\hline $\boldsymbol{b}$ & $\mathbf{- 0 . 0 1 9 0 1}$ & 0.007637 & -2.48942 & $\mathbf{0 . 0 1 7 8 4 9}$ \\
\hline
\end{tabular}

\section{CONCLUSION}

It could be concluded that most hematological parameters of quail have changed according to the genotype.

\section{REFERENCES}

Abd El-Aziz, D. F. 2006. The use of modern biotechnology in the production of high immune response chickens. M Sc. Thesis Faculty of Agriculture Alex, University of Egypt

Aly, O.M., Abou El-Ell and Nazla, Y. 2006. Effect of crossing on the performance of local strains 2 estimates of pure line difference, direct Heterosis, maternal additive and direct additive effect for growth traits, viability and some carcass traits. Egypt Poult. Sci. (26) (I): 53-67.

Archer, R. K. 1965. Hematological technique for use on animals. Black wall scientific publications oxford

Cerolini S, Baladi A. and Cavalchini LG. 1990. Blood and plasma biochemical variables in laying hens of different strains and ages. Arch Geflugelkd 1990; 54: 190-194

Deif, E. A., Galal, A., Fathi, M. M. and Zein El-Dein, A. 2007. Immunocompetence of two broiler strains fed Marginal and high protein diets. International journal of poultry science 6(12)901-911

Dowidar, Y.A., R.Y. Nafal and Afifi, Y.K. 1999. Carcass and some serum biochemical traits of males of three local Egyptian chicken strains. Egypt. Poultry Sci., 19(II): 395-406.

Duncan, D. R. (1955): Multiple ranges and multiple F test. J. Biometrics. 1, 1- 42

El-Kaiaty, A.M., and Hassan M.S. H. 2004. Some physiological and immunological parameters in the females of local chicken strains. Egypt. Poultry Sci. 24 (IV): 901-916.

Elnaggar, Samar A., Azza El-Sabai, and M. Abaza 2001. Manipulation of thyroidal activity in broiler chick. 1. Birds performance, Physiological and biochemical observation. Egypt. Poultry Sci. 21: 1101-1119.

El-Tahawy, W.S.A. 2005. Production of transgenic local chicken by injection of DNA from Japanese or broiler breeders. Ph.D. Thesis, Fac. Of Agric. Damanhour Branch, alex. Univ. Egypt

Farahat, G. S. Nadia, M. and Omhashem, Y. M. 2010. genetic parameter estimates for glutathione peroxidase and some blood constituents and their association with some growth traits in Japanese quail. Egypt. poult. Sci. (30) (iii): (847873)

Fathi, M.M.; El-Safty, S.A.; Galal, A. and Ali, U. M. 2005 Immunological responses of Frizzie and Normally feathered genotypes issued from different maternal lines of chickens. Egypt Poultry Sci. (25) (II): 429-444.

Galal, A., Abdel-Motaai, A. M., Ahmed, A. M. H. and Zaki, T. G. 2008. productive performance and immune response of laying hens as affected by dietary propolis supplementation. International journal of poultry science 7(3) 272-278

Gyenis J, Suto Z, Romvari R, Horn P. 2006. Tracking the development of serum biochemical parameters in two laying hen strains - a comparative study. Arch Tierzucht; 49: 593-606.

Jatoi1. A. S., Sahota. A. W., Akram. M., Javed. K., JaspaL. M. H., Hussain. J., Mehmood. S., Abbas, Y., Mirani. A. H. and Ishaq. H. M. 2015. The effect of different body weight categories on plasma macromineral levels in four Closebred flocks of adult Japanese quails (Coturnix coturnix japonica), Turkish Journal of Veterinary and Animal Sciences, 39: 343-349

Kosshak, A. S., Dim, N. I., Momoh, O. M. and Gambo D. 2014. Effect of sex on carcass characteristics and correlation of body weight and blood components in Japanese quails. Journal of Agriculture and Veterinary Science 7(11): 72- 76

Lesson S. and Summers J.D. 2005. Commercial poultry nutrition. Nottingham University

Mahrous, M.Y. and El-Dlebshany, A.M. 2011. Reduction of the cholesterol content of eggs by introducing naked neck $(\mathrm{Na})$ and frizzle genes in laying hens. Egyptian Poultry Science 31: 817-824

Mahrous, M.Y., Galal, A., Fathi, M.M. and Zein EL-Dein, A. 2008. Impact of naked neck $(\mathrm{Na})$ and frizzle $(\mathrm{F})$ genes on growth performance and immunocompetence in chickens. International Journal of Poultry Science 7: 45-54.

Makram, A., A. Galal and A.H. El-Attar 2014. Hematological and Immunocompetence Parameters of Sudani, Peking Duck Strains and their cross. 7 th International Poultry Conference - Proceeding

Muhammad H. K. 2013. Study the effect of age and sex on some hematological parameters in golden local quail. J. Vet. Res. 12(1) 135-141.

Pavlik A, Lichovnikova M, Jelinek P. 2009. Blood plasma mineral profile and qualitative indicators of the egg shell in laying hens in different housing system. Actavet Brno; 78: 419429.

Peters, S.O., Gunn, H.H., Imumorin, I.G., Agaviezor, B.O. and Ikeobi, C.O.N. 2011.Hematological studies on frizzled and naked neck genotypes of Nigerian native chickens. Tropical Animal Health and Production 3: 631-638.

SAS Institute. 2010. SAS®/STAT Software, Release 9.2. SAS Institute, Inc., Cary, NC. USA.

Suchy P, Strakova E, Vecerek V, Sterc P. 2000. Biochemical studies of blood in hens during the laying period. Czech J Anim. Sci. 46: 383-387.

Uduak, O . E., Okoro V. M. O., Okeke G. U., Durugo N., Mbaebie G. A. C. and Ezebuike C. I. 2013.Effects of age breed and sex on the serum biochemical values of Turkeys (Meleagridis gallopova) in South-eastern Nigeria. African Journal of Agricultural Research 8(23) 2825-282.

Varley, H., Gowenlock, A. H. and Bell, M. 1980. Practical Clinical Biochemistry. 5th ed. William Heinemann Medical Books Ltd.,London . 